\title{
Health-Promoting Churches: Reflections on Health and Healing for Churches on Commemorative World Health Days, by Mwai Makoka, World Council of Churches Publications, Vol. 1, 2020;
} Vol. 2, 2021

\section{Arnold L Gorske}

\begin{abstract}
a MD, FAAP. CEO, Standards of Excellence in Healthcare Missions. Editor, Health Education Program for Developing Communities (HEPFDC.org), USA
\end{abstract}

It is difficult to overemphasize the importance of these two small handbooks. Other than the Bible, they have more lifesaving, health and healing potential than anything else I have read in more than 50 years as a physician. The purpose of both volumes by Dr. Mwai Makoka, WCC Programme Executive for Health and Healing, is to help reestablish the local church's mission as a healing community. This is not a new concept; until the past two generations, the Church followed the example of Jesus' holistic healing ministry, and most hospitals were established by the Church.

Volume I gives churches starting points for conversations and action on different health topics chosen from the World Health Organization (WHO) calendar. ${ }^{1}$ For example, though the section on "World Immunization Week" was written before COVID-19, churches could apply the principles and current WHO guidelines to COVID-19 vaccine hesitancy and do much to prevent the tragic numbers of unnecessary deaths due to false information.

Volume II is especially important as it provides comprehensive guidelines to enable every congregation to reassume its health and healing responsibilities. ${ }^{2}$ Both volumes are "expected to support the healing ministry of the local congregation to ensure that: 1 . The church is a place of health education. 2. The church is a place of practical action. 3. The church is a place for advocacy and care for creation, and 4 . The church is a place of empowerment for public witness." (Vol. I, p. 1; Vol. II, p. ix)

The volumes may be downloaded free as a service of the World Council of Churches (WCC). Volume I is available in English, French, and Spanish. Volume II is available in English with French and Spanish translations pending.

As ministries of health throughout the world follow WHO guidelines, it is important to emphasize that these handbooks are not only Biblically-based but also based on WHO international standards and guidelines. Remarkably, both volumes have even been endorsed by the Director General of the WHO Tedros Adhanom Ghebreyesus. This is essential for those of us working in the secular world, especially in restrictive access settings.

This is not a new collaboration. It was Christian missionaries who originated WHO's primary care system with its health promotion and prevention back in the 1960s, and WHO's Declaration of Alma Ata was coauthored by a Christian missionary. ${ }^{3}$ These same missionaries reported, "One of the most urgent needs of to-day is that Christian congregations, in collaboration with Christian medical workers, should again recognise and exercise the healing ministry which belongs properly to them ..." ${ }^{4}$ (p. 14) 
It is also important to recognize why these simple handbooks are potentially world changing. WHO's World Health Report 2008: Primary Health Care-Now more than Ever ${ }^{5}$ emphasizes the following as one of the most critical mistakes in both developed and developing countries: "Misdirected care: Resource allocation clusters around curative services at great cost, neglecting the potential of primary prevention and health promotion to prevent up to $70 \%$ of the disease burden." (p. xiv)

Although most churches do not have the financial or physical resources to provide modern curative care services, all churches have the human and community assets to provide lifesaving evidence-based holistic education and interventions for health promotion and disease prevention (the 70\%). This has also long been emphasized by WHO's Building from Common Foundations: The World Health Organization and Faith-Based Organizations in Primary Healthcare. ${ }^{6}$

The discipline of public health provides an opportunity for churches to develop community health ministries. This remains the key to community transformation and the success of healthcare systems in both developed and developing countries. The highly respected medical journal, The Lancet, reports:

The missing link in the translation of the principles of Alma-Ata from idealism to practical, effective strategies has been the failure to integrate the perspective of personal and public health. The future of health care generally, and primary care specifically, depends on the integration of personal health care and public health at the level of the local community. ${ }^{7}$

As reported in Health-Promoting Churches, Volume I, for those who follow the example of Jesus, "The Christian ministry of healing belongs primarily to the congregation as a whole, and only in that context to those who are specially trained."(p. iii) Yet health professionals who follow evidence-based guidelines are also essential. Nurses, community health workers, and health educators have been especially effective in assisting congregations in their holistic health promotion and disease prevention services both locally and on the mission field. ${ }^{8}$

As has again been demonstrated with COVID19 , it is important to recognize that healthcare information not evidence-based can harm as many people as curative care not evidence based. Through its constitution and 193 member states, the WHO is responsible for "setting norms and standards" and requires its guidelines be based on the best available evidnce. ${ }^{9}$ Numerous Biblical/WHO evidence-based guidelines addressing our most important healthcare problems are now available free in multiple languages to meet these requirements. ${ }^{10}$

Church-based community health utilizing evidence-based guidelines is especially important for prevention of the ever-increasing deaths due to unhealthy lifestyle. The WHO reports at least $80 \%$ of chronic diseases, such as diabetes, heart disease, and stroke, could be prevented by simple lifestyle changes. ${ }^{11}$ These diseases are also the leading risk factors for deaths due to COVID-19. However, even before COVID-19, unhealthy diet had become the leading cause of early death and disability in the world. $^{12}$ For example, The Lancet Commission reported, "Unhealthy diets pose a greater risk to morbidity and mortality than does unsafe sex, and alcohol, drug, and tobacco use combined." In addition:

The Commission quantitatively describes a universal healthy reference diet, based on an increase in consumption of healthy foods (such as vegetables, fruits, whole grains, legumes, and nuts), and a decrease in consumption of unhealthy foods (such as red meat, sugar, and refined grains) that would provide major health benefits and also increase the likelihood of attainment of the Sustainable Development Goals. ${ }^{13}$

Here again, WHO's Interventions on Diet and Physical Activity: What Works gives local church programs for health promotion and prevention its highest evidence-based rating for effectiveness. ${ }^{11}$ 
The only significant weaknesses we could find were due to the brevity of the handbooks. However, additional supporting documentation is readily and abundantly available elsewhere. A few recently published examples follow.

For those who wish more Biblically-based evidence, All Creation Groans: Toward a Theology of Disease and Global Health ${ }^{14}$ provides an even more comprehensive and compelling theological foundation for reestablishing the healing mission of the congregation in our modern-day world.

Setting up Community Health Programmes in Low and Middle Income Settings-4th ed ${ }^{15}$ (Can be downloaded free) and Beyond Poverty-Multiplying Sustainable Community Development ${ }^{16}$ provide simple and effective guidelines on how best to enable communities to lift themselves out of poverty and disease and initiate "transformational movements that multiply change from village to village and sweep the countryside." (p.ix)

The Health-Promoting Churches handbooks emphasize that even small congregations can follow the health and healing example of Jesus and "let your light shine before others, so that they may see your good works and give glory to your Father who is in heaven." (Matthew 5:13-16, NIV). Allen, ${ }^{17}$ Yorgin, ${ }^{18}$ and others ${ }^{19}$ have provided additional guidelines on the importance of simple church-based health fairs in meeting these requirements. Probably more than any other activity, church-based, holistic health fairs enable more congregation members (from teenagers to grandparents to healthcare professionals) to accomplish the above and do it in a fun-filled, joyful setting as well. They also provide important introductions to available community services as well as both curative care and churchbased health promotion/ prevention follow-up.

Numerous additional examples of churches that are following the holistic health and healing example of Jesus can be found on the Best Practices in Global Health Missions ${ }^{20}$ website. See especially The Church \& Healthcare ${ }^{21}$ and Health Promotion \& Education $^{10}$ for additional Biblical and WHO international, evidence-based guidelines and resources that can be downloaded free.

Reestablishing Jesus' holistic healing ministry may well be the key to resolving problems related to declining church attendance as well as our lifestylerelated, declining health. Churches with declining attendance will grow as they meet the needs of the people in their community. Pastors are also now reporting that "engagement (of individual church members) will drive almost all future church growth." 22 As emphasized by Health-Promoting Churches, every congregation should have a Church Health Committee:

"The hub of the Health-Promoting Church is the church health committee (CHC), which leads the health ministry. It should represent the full diversity of the local church. The main criteria for membership in the committee are passion for health issues, willingness to work as a team, and ability to organize and motivate others. Church members who are trained health professionals are encouraged to participate in the committee without having to dominate it. Besides the $\mathrm{CHC}$, all church members should be encouraged to participate and contribute with their gifts and abilities as much as possible." Dr. Isabel Apawo Phiri, Deputy General Secretary for Public Witness and Diakonia World Council of Churches (Vol. I, p. xi)

Christianity is the largest religious group in the world, and in 2020 there were about 2.6 billion adherents globally ${ }^{23,24}$, and the numbers of churches are multiple times the numbers of hospitals and clinics in many countries. From a Biblical and WHO evidence-based standpoint, the local congregation is currently the world's most qualified and underused health and healing resource. ${ }^{3,4,6,7,11,19,20,21}$ Our prayer is that all who read this review will forward the links to these two volumes to every pastor, theologian, and health professional they know, especially those with influence in seminary, Bible school, and health 
training institutions. Never has the need or the opportunity been greater.

\section{References}

1. Makoka M. Health-promoting churches. Reflections on health and healing for churches on commemorative world health days [Internet]. Geneva:World Council of Churches [WCC] Publications. 2020. [English, French, and Spanish]. [cited 2021 Sept]. Available from: https://www.oikoumene.org/resources/publications/he alth-promoting-churches

2. Makoka M, Ed. Health-promoting churches. A handbook to accompany churches in establishing and running sustainable health promotion ministries [Internet]. Vol. 2. Geneva:WCC Publications. 2021. [English, French, and Spanish translations pending]. [cited 2021 Sept]. Available from: https://www.oikoumene.org/resources/publications/he alth-promoting-churches-volume-ii

3. Gorske A. Christian contributions to international standards \& guidelines (IS\&Gs) [Internet]. [cited 2021 Sept]. Available from: https://www.bpghm.org/health_topics/christiancontributions-to-international-standards-guidelinesisgs/

4. McGilvray JC. The quest for health and wholeness [Internet]. Tubingen: German Institute for Medical Missions. Herausgeber: Deutsches Institut für ärztliche Mission. Paul-Lechler-Straße 24, 7400 Tübingen; 1981 [cited $2021 \mathrm{Sept}$ ]. Available from: https://difaem.de/fileadmin/Dokumente/Publikationen /Dokumente_AErztliche Mission/webThe Quest for _Health and Wholeness.pdf

5. World Health Organization. World Health Report 2008: Primary health care - now more than ever [Internet]. Geneva:World Health Organization; 2008 [cited 2021 Sept]. Available from: https://www.who.int/whr/2008/whr08 en.pdf

6. World Health Organization. Building from common foundations: The World Health Organization and faith-based organizations in primary healthcare [Internet]. Geneva:WHO; 2008. [cited 2021 Sept]. Available from: http://apps.who.int/iris/bitstream/handle/10665/43884/ 9789241596626 eng.pdf;jsessionid=A15242C3BD8D 2E3E398075ADCDA8E9ED?sequence $=1$
7. Van Weel C, De Maeseneer J, Roberts R. Integration of personal and community health care. Lancet. 2008;372(9642). P871-2. https://doi.org/10.1016/S0140-6736(08)61376-8

8. Nursing. Best practices in global health missions (BPGHM) [Internet]. [cited 2021 Sept]. Available from: https://www.bpghm.org/health topics/nursing/

9. World Health Organization. WHO handbook for guideline development 2 nd ed. [Internet]. Geneva:WHO; 2014. [cited 2021 Sept]. Available from: https://apps.who.int/iris/handle/10665/145714

10. Health Promotion \& Education. Best practices in global health missions [Internet]. [cited 2021 Oct]. Available from: https://www.bpghm.org/health topics/healthpromotion-education/

11. World Health Organization. Interventions on diet and physical activity: what works [Internet]. Geneva:WHO Publications; 2009. [cited 2021 Oct]. Available from: https://www.who.int/dietphysicalactivity/summaryreport-09.pdf

12. Nutrition programs. Health education program For developing communities (HEPFDC) [Internet]. [cited 2021 Sept]. Available from: https://hepfdc.org/nutrition-programs/

13. The Lancet Commission. Food in the anthropocene: the EAT-Lancet Commission on healthy diets from sustainable food systems. Lancet. 2019. Available from: https://www.thelancet.com/commissions/EAT

14. O'Neill DW, Snodderly B, editors. All creation groans: toward a theology of disease and global health. Eugene, Oregon: Pickwick Publications; 2021. Available from: https://wipfandstock.com/9781725290112/allcreation-groans/

15.Lankester T, Grills NJ, editors. Setting up community health programmes in low- and middle-income settings. $4^{\text {th }}$ ed. Oxford University Press, 2021. Available open access from: https://oxfordmedicine.com/view/10.1093/med/97801 98806653.001.0001/med-9780198806653

16. Dalrymple T. Beyond poverty-multiplying sustainable community development. Littleton, CO: William Carey Publishing; 2021:80129. Available from: https://missionbooks.org/products/beyond-poverty 
17. Allen EA. The Church for whole person healing. Wholistic screening \& education activities in church health fairs [Internet]. [cited 2021 Sept]. Available from: https://faithandhealth.files.wordpress.com/2017/01/wh olistic-screening-and-education-activities-in-churchhealth-fairs1.pdf

18. Yorgin P. Resources. Church-based health screening and education fairs around the world. [cited 2021 Oct]. Available from:

https://www.medicalmissions.com/resources/4082/ch urch-based-health-screening-and-education-fairsaround-the-world

19. SYSTEM 3: CHE\&S. Church/community health fairs. Health education program For developing communities (HEPFDC) [Internet]. [cited 2021 Oct]. Available from: https://hepfdc.org/pdfviewer/system3-ches-church-community-healthfairs/\#page=\&zoom=\&pagemode=none
20. BPGHM. Health topics. best practices in global health missions [Internet]. [cited 2021 Oct]. Available from: https://www.bpghm.org/health-topics/

21. BPGHM. The church \& healthcare. Best practices in global health missions [Internet]. Cited 2021 Oct. Available from: https://www.bpghm.org/health topics/church-andhealthcare/

22. Nieuwhof C. 7 ways to grow the Church by increasing engagement [Internet Blog] 102. [cited 2021 Oct]. Available from: https://careynieuwhof.com/7-waysgrow-church-attendance-increasing-engagement/

23. List of Christian denominations by number of members. Wikipedia, the free encyclopedia. [cited 2021 Oct]. Available from: https://en.wikipedia.org/wiki/List_of_Christian_deno minations by number_of members

24. Johnson TM; Grim BJ, editors. "All religions [global totals]." World religion database. Leiden, Boston: BRILL, Boston University; 2021 [cited 2021 Oct]. Available from: https://worldreligiondatabase.org/

Submitted 25 Oct 2021, accepted 27 Oct 2021, published 27 Dec 2021

Competing Interests: None declared.

Acknowledgements: I wish to thank the following for their contributions to this review: Pastor Mark Dahle, Daniel Dugan PhD, Robert Ellwood PhD, Nathan Grills MD, Vicki Hesterman PhD, Judith Lasker PhD, Elenore Lugo RN, Michael McLaughlin MDiv, Jason Paltzer PhD, John Payne MD, Laura Smelter MD, Grace Tazelaar RN, and Peter Yorgin MD.

Correspondence: Arnold L Gorske, Standards of Excellence in Healthcare Missions; Health Education Program for Developing Countries (HEPFDC.org), USA. arnoldgorske@gmail.com

Cite this article as: Gorske AL. Health-Promoting Churches. Reflections on Health and Healing for Churches on Commemorative World Health Days, by Mwai Makoka. Vol. 1, 2020; Vol.2, 2021. Christ J Global Health. December 2021; 8(2):36-40. https://doi.org/10.15566/cigh.v8i2.591

(C) Author. This is an open-access article distributed under the terms of the Creative Commons Attribution License, which permits unrestricted use, distribution, and reproduction in any medium, provided the original author and source are properly cited. To view a copy of the license, visit http://creativecommons.org/licenses/by/4.0/

www.cjgh.org

Dec 2021. Christian Journal for Global Health 8(2) 